\title{
"The Impact of Ramadan month on market stock returns anomalies: an empirical investigation of Palestine Exchange (PEX)"
}

\begin{tabular}{|c|c|}
\hline AUTHORS & $\begin{array}{l}\text { Ashraf S. Hijazi } \\
\text { Mosab I. Tabash (D https://orcid.org/0000-0003-3688-7224 }\end{array}$ \\
\hline ARTICLE INFO & $\begin{array}{l}\text { Ashraf S. Hijazi and Mosab I. Tabash (2020). The Impact of Ramadan month on } \\
\text { market stock returns anomalies: an empirical investigation of Palestine Exchange } \\
\text { (PEX). Investment Management and Financial Innovations, 17(1), 253-265. } \\
\text { doi:10.21511/imfi.17(1).2020.22 }\end{array}$ \\
\hline DOI & http://dx.doi.org/10.21511/imfi.17(1).2020.22 \\
\hline RELEASED ON & Monday, 30 March 2020 \\
\hline RECEIVED ON & Saturday, 08 February 2020 \\
\hline ACCEPTED ON & Monday, 16 March 2020 \\
\hline LICENSE & $\begin{array}{l}(c) E Y \text { EY } \\
\text { This work is licensed under a Creative Commons Attribution } 4.0 \text { International } \\
\text { License }\end{array}$ \\
\hline JOURNAL & "Investment Management and Financial Innovations" \\
\hline ISSN PRINT & $1810-4967$ \\
\hline ISSN ONLINE & $1812-9358$ \\
\hline PUBLISHER & LLC "Consulting Publishing Company "Business Perspectives" \\
\hline FOUNDER & LLC "Consulting Publishing Company "Business Perspectives" \\
\hline
\end{tabular}

NUMBER OF REFERENCES

37
NUMBER OF FIGURES

1
NUMBER OF TABLES

9

(C) The author(s) 2022. This publication is an open access article. 


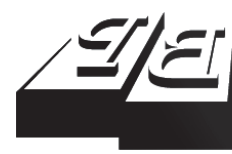

\section{BUSINESS PERSPECTIVES}

LLC "CPC "Business Perspectives" Hryhorii Skovoroda lane, 10, Sumy, 40022, Ukraine www.businessperspectives.org

Received on: $8^{\text {th }}$ of February, 2020 Accepted on: $16^{\text {th }}$ of March, 2020 Published on: $30^{\text {th }}$ of March, 2020

(c) Ashraf S. Hijazi,

Mosab I. Tabash, 2020

Ashraf S. Hijazi, Lecturer, Department of Commerce, Islamic University of Gaza, Palestine. (Corresponding author)

Mosab I. Tabash, MBA Director, College of Business, Al Ain University, United Arab Emirates.

\section{THE IMPACT OF RAMADAN MONTH ON MARKET STOCK RETURNS ANOMALIES: AN EMPIRICAL INVESTIGATION OF PALESTINE EXCHANGE (PEX)}

\begin{abstract}
The main purpose of the current study is to examine the impact of Ramadan month on stock returns at the Palestine Exchange (PEX). The study sample consists of all Palestinian public shareholding companies listed in the PEX. The comparison period used in this study consists of 30 days before Ramadan month, 30 days after Ramadan month, and Ramadan month (30 days). This gives a total of 90 days in a year for ten years (2006-2016). The GJR-GARCH technique is used. The results of the study show that Ramadan month has a remarkable effect on the stock returns of the companies in the PEX. The results indicate a significant impact on earnings per share (EPS) in the PEX. Furthermore, there is a positive relationship between the stock returns and the market value in Ramadan month. The profits are increased in the industrial and investment companies due to the high demands in Ramadan month. Therefore, the companies should work to keep a steady performance in the whole year. Besides, the capacity of industrial and investment companies should be increased to meet the high demand in Ramadan month. This study will help Palestinian investors to effectively time their trading. This study is considered one of the pioneering studies that discuss the impact of Ramadan month on the stock returns in the context of Palestine Stock Exchange.
\end{abstract}

Keywords Ramadan, Islamic calendar, PEX, stock returns, industrial and investment companies

\section{JEL Classification $\quad$ G11, G14, G23}

\section{INTRODUCTION}

According to behavioral finance, most investors are rational. They update their beliefs in the right way when there is new information (Pesaran, 2005). Fama (1970) stated that an efficient market is a market where investors can be freely trading in the stock markets with full availability of information. This is supported by Reilly and Brown (2004) who said that an efficient stock market has a high response for new information. The rationality of market efficiency was attacked by different policymakers (Lo, 2005). Aduda, Oduor, and Omwonga (2012) said that people suffer from emotional biases and behave in a seemingly irrational way.

The anomalies of efficient markets were the main topic for several former studies. They all gave clear evidence that the efficient market hypothesis holds certain unexpected deviations in the movement of price(s). Having the idea of coherent and correlated predictions, the price gives all the related information. This makes the market effective. Aside from the above, the relationship between the price and the data, the stakeholders can hardly have inconsistent funds (Fama, 1970). Otherwise, in reality, abnormal returns can occur due to different 
shifts in stock prices that are caused by some sudden reactions. EMH anomalies are the main interest in the academic field, such as the effect of January (Branch, 1977), the ignored effect of firms (Arbel \& Strebel, 1983), the effect of exchange listing (Ritter, 1991), and the effect of size (Reinganum, 1992).

Schwert (2003) defined an anomaly as the deviation, which changes relatively from a model behavior of normal return in which depends on various market efficiency levels. In the financial market, anomaly means when the return of the stocks is deviating from the EMH assumptions (Latif, Arshad, Fatma, \& Farooq, 2011). Fama (1970) explained it over three market forms of efficiency: weak-form, semi-strongform, and strong-form. The existence of abnormal returns is considered even if the market is in the weakest form of efficiency because the available information is not reflected by the existing price (Jensen, 1978). Furthermore, sometimes, "anomaly" as a term is misapplied and misused. Modern finance theory considers anomaly as a model of an EMH shortage in explaining the movement of the price and a failure to develop behavioral finance. Anomaly originally means the irregularity that could appear because of common or natural order deviation. The occurrence of an anomaly is simply expected because there is a possible mismatch between what the theory supposed to happen and what happens in reality on the ground. Before understanding anomaly and by supposing that it is a "puzzle," which has been solved, then what could be the meaning of anomaly if it does not exist anymore. The academic literature recognized the word "effect" to illustrate the EMH theory "puzzle" and help in maintaining neutrality (Frankfurter \& McGoun, 2001). This study examines the impact of Ramadan month on the stock returns anomaly in the Palestine Exchange (PEX). The Palestine Exchange (PEX) is a new stock exchange established in 1995. It provides Palestinian investors an opportunity to trade in different sectors with full disclosure and transparency. In 2012, it had 46 listed companies with a gross capitalization reaches to USD 3 billion in different sectors like services, insurance, financial services. Not too many studies study the impact of Ramadan month on stock market returns in the case of Palestine.

More interestingly, Palestine lags behind the most emerging economies in the world due to its situation as it is occupied and largely depends on donations and international aids from the whole world. Therefore, the output of this study will be very beneficial for policymakers, finance scholars, and bankers at the global level to develop their strategies accordingly. Moreover, the main three objectives are to find out the impact of Ramadan month on stock returns anomalies:

1. To check the change in stock returns arising from Ramadan month effect in the PEX.

2. To find out the impact of pre and post Ramadan month anomalies in the PEX share index in the study period.

3. To examine the effect of Ramadan month on stock returns anomaly in the PEX.

\section{LITERATURE REVIEW}

Most of the studies in the area of market anomalies are done in developed countries, including day-ofthe-week effect (Kiymaz \& Berument, 2003; Kulavi, 2013) holiday effect (Marrett \& Worthington, 2007; Dodd \& Gakhovich, 2011; Rasugu, 2005; Osman, 2007), and turn-of-the-month effect (Waithaka, 2013; Ray, 2012), among others. The findings prove these anomalies. There is a shortage in these studies in developing or emerging markets, especially in the countries that follow the Islamic way of in- vestment like Palestine. Islamic finance has now a momentum in the world, particularly Islamic equities return (Sultan \& Malik, 2013). This is because Islamic finance is growing fast in the last decade (Alrashidi, 2013). Calendar anomalies are present in the Islamic indices where there is a significant number of Muslim investors. Most of the Muslim countries relate to emerging economies like this study.

Most of the Islamic countries use dual banking sector, including the Islamic banking system, in 
their transactions, and it is confirmed that Islamic banking has contributed to the growth of the economies (Tabash \& Dhankar, 2014). The current study shows the impact of Ramadan on the Islamic stock market. During Ramadan, Muslims are involved in religious activities like fasting, reciting prayers, and the Holy Quran. Muslims spend most of their time performing religious activities, which, in turn, leads to slowing down activities related to investing in stock markets. At the same time, the month also attracts new investors by generating new business opportunities.

Białkowski et al. (2012) concluded that stock returns are nine times higher in the middle of Ramadan and less unstable in the middle of any other month of the year. Many studies have discussed potential causes for the anomalies. However, no research found a full answer regarding the volatility of returns in specific days or month, especially in Ramadan. One of the first studies in Palestine was done by Mustafa (2008) who examined the Islamic calendar effects on the daily returns of Palestine Exchange. His results confirmed that Ramadan month effect exists in all models and argued that PSX is a very risky market during Ramadan month.

Khan et al. (2018) examined the performance of Islamic stock indices in the presence of Islamic calendar anomaly in the context of emerging economies. They used Standard \& Poor's (S\&P) Shariah index, which comprises funds from 22 emerging economies. The Generalized Auto Regressive Conditional Heteroscedasticity model is used to catch the seasonality in the returns and the volatility of the Islamic equity market. It has been found out that the effect of Ramadan, the holy month of Muslims, can be both significant and insignificant, depending on different years. The financial deviations in the Islamic regularities are the core point of certain researches. These declare that the stock funds on specific events of Muslims are more likely to happen. These events are like Ashura, Ramadan, Eid al Fitr, Eid Mawlid al-nabi (SAW), and Eid al Adha (Białkowski, Etebari, \& Wisniewski, 2012; Husain, 1998).

In the Tunisian stock market, a study revealed that the economy is affected by Ramadan more than any other time of the year (Rehomme \&
Rejeb, 2008). Białkowski et al. (2012) revealed that the stock price inconsistency in the Holy month in 14 different markets, excluding the Turkish, is declined. Ramezani, Pouraghajan, and Mardani (2013) showed that Tehran Stock Exchange corresponds with the positive effect of Ramadan, while the Istanbul Stock Exchange is not affected by Ramadan (Alper \& Aruoba, 2001). The Saudi stock market is the main core of interest of the study by Seyyed, Abraham, and Al-Hajji (2005). Their results showed that Ramadan does not change the mean funds. However, a reduction of inconsistency occurs. Excluding the Bahrain stock market, which is the smallest in the Gulf region, the Gulf countries showed that the Holy Eid al-Fitr extremely affected the funds (Bley \& Saad, 2010). Moreover, as revealed by McGowan and Jakob (2010), Eid al-Fitr does not affect the Malaysian stock market. Chowdhury and Mostari (2015) found that Ashura and Eid Mawled an-Nabi (SAW) have a great impact on the Dhaka Stock Exchange. Some researchers found no effect of Ramadan on other stock markets (Al-Ississ, 2010; Majeed et al., 2015). In this study, new fresh insights of the impact of Ramadan on the stock returns in Palestine are discussed.

\section{METHODS}

\subsection{Research design}

The methodology of the study was based on the GJR-GARCH Model by Glosten et al. (1993). It is a method applied to analyze the anomalies and their effect on stock returns. Following the normality assumption of $z t, \gamma$ is multiplied by $1 / 2$. The impact of Ramadan on the volatility of stock returns is shown in equation 1 .

$$
\begin{aligned}
& \mu_{t}=E\left(\frac{r_{t}}{F_{t-1}}\right)=\lambda_{0}+\lambda_{1} \cdot D_{t}+ \\
& +\sum_{i=1}^{k} \phi\left(r_{t-i}-\mu_{t-i}\right)+\sum_{j=1}^{q} \theta_{j} \varepsilon_{t-j}+\varepsilon_{t} \\
& \sigma_{t}^{2}=w+\delta D_{t}+\sum_{i=1}^{p}\left(\alpha+\gamma I_{t-1}\right) \cdot \varepsilon_{t-1}^{2}+ \\
& +\sum_{j=p+1}^{q} \beta \sigma_{t-1}^{2} .
\end{aligned}
$$


This equation 1 shows that the autoregressive moving average process of $k$ and $l$ order is consecutively formed, $D_{t}, 1$ in Ramadan month, is a dummy variable. Return series $r_{t}$ is generally defined as first difference of natural log of stock prices $P_{t}: r_{t}=\ln \left(P_{t}\right)-\ln \left(P_{t-1}\right)$, in which $P^{\prime}$ shows that the stock price is adapted to the capital change in time $t$ (e.g. dividend, rights issues, etc.). $\sigma_{t}^{2}$ is conditional variance equation. $\varepsilon_{t}$ is the error term. $\theta_{j}$ is the effect of the excluded dummy variables. $\beta$ shows that market volatility. All the conditions of the GJR-GARCH model are estimated at the same time with ML estimator.

\subsection{Sampling and companies' selection criteria}

The study consists of all Palestinian public shareholding companies listed in the PEX between 2006 and 2016. The following conditions are considered for the listed companies:

- The company is listed on the Palestine Stock Exchange.

- The company has been investing from 2006 until 2016 since the data available as of year 2006.

- The company has not stopped trading during the study period (2006-2016).

- It should not be added during the study period.

- The financial year should be completed in December of each year.
- The availability of the companies' data during the study period to measure the variables.

Based of the above criteria, 32 companies were selected for the study. The comparison period for this research comprised of 30 days before Ramadan and 30 days after Ramadan, and Ramadan month (30 days) (Figure 1). This gives a total of 90 days in a year. The period of the study spans from 2006 to 2016 .

The daily stock returns for the event window and comparison period were computed using the following formula:

$$
R_{x}=P_{x}-P_{x-1},
$$

$R_{x}$ - daily market returns, $P_{x t}$ - market closing prices for day $t$, and $P_{x-1}$ - market closing price for day $t-1$ (previous day). The mean daily return was calculated for both the event window and comparison periods. SPSS was used to analyze the data.

\subsection{Measurement of Ramadan effect}

GJR-GARCH is a method applied to analyze the anomalies and their effect on stock returns. The empirical observations show that when compared to positive shocks, the variance in the day $t$ is affected by the negative shocks in the day $t-1$. This confirms that the GJR-GARCH method is better than GARCH model. $(\alpha+\gamma)$ is the efficient coefficient related to a negative shock. However, $\gamma$, which is statistically significant, reflects the negative chocks in the financial times series. (Glosten

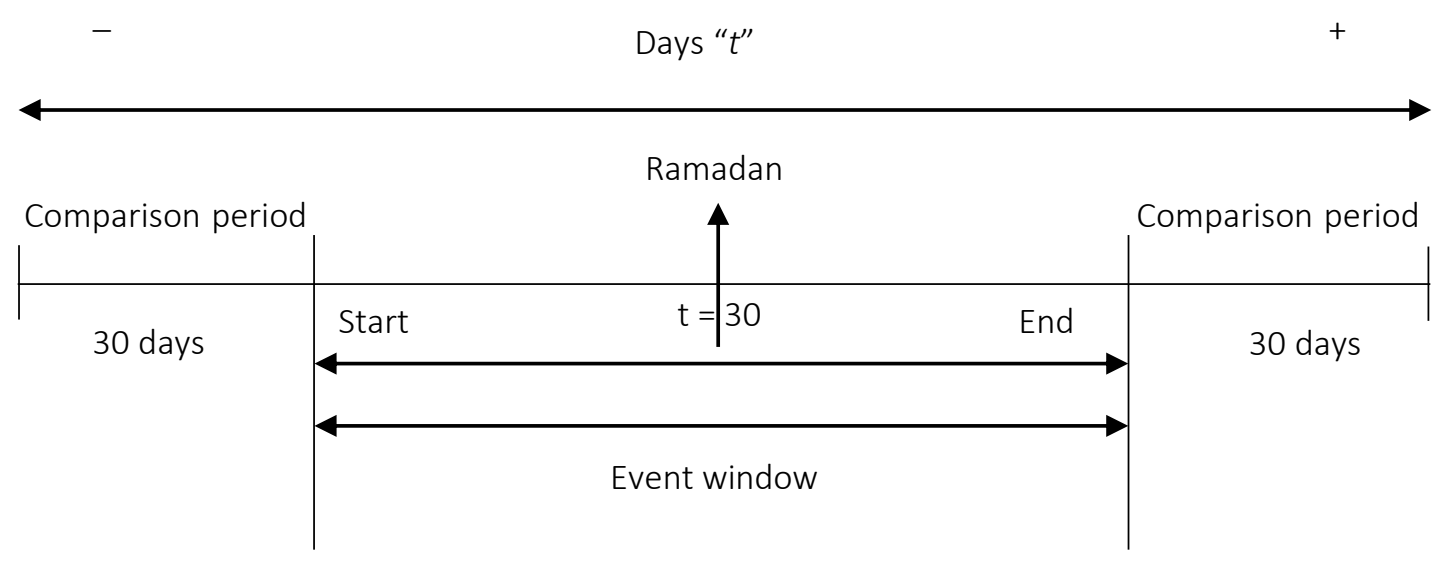

Figure 1. Event period of 90 days 
et al., 1993). According to the GJR-GARCH model, there is a return series $\left(r_{t}=\mu_{t}+\varepsilon_{t}\right)$ that consists of expected return series $\left(\mu_{t}\right)$ and zero-mean white noise term $\left(\varepsilon_{t}\right) \cdot \mu_{t}=E\left(r_{t} / F_{t-1}\right)$ is the mean of the time series $r_{t}$ given the information set $F_{t-1}$ and $\sigma_{t 2}=\operatorname{Var}\left(r_{t} / F_{t-1}\right)$ is the conditional variance.

$\varepsilon_{t}$ is the iid innovations with mean zero and variance. $\varepsilon_{t}$ does not have to be successively independent, even though it is serially uncorrelated. For instance, if one assumes that the conditional heteroscedasticity is present, GJR-GARCH model will suggest that there is a specific form for it. When given the assumed standard Gaussian - the $\varepsilon_{t}=\sigma_{t} z_{t}$ with $z_{t}$ variance, it gives $\varepsilon_{t}-$ GJRGARCH. Consequently, it leads to the following:

$$
\begin{gathered}
\sigma_{t}^{2}=\omega+\left(\alpha+\gamma I_{t-1}\right) \varepsilon_{t-1}^{2}+\beta \sigma_{t-1}^{2}, \\
I_{t-1}=\left[\begin{array}{lll}
0 & \text { if } & r_{t-1} \geq \mu \\
1 & \text { if } & r_{t-1}<\mu
\end{array}\right] .
\end{gathered}
$$

In model 2, all the parameters could be valued with maximum likelihood estimator at the same time, excluding the leptokurtic returns. The GJRGARCH model shows good results related to volatility and clustering of the time series. If volatility is high in day $t-1$, it will likely to be higher in time $t$ accordingly, the variance in $t$ is affected by a shock in day $t-1$. But volatility itself returns average (mean reverting) if $\alpha+(\gamma / 2)+\beta<1$ and it will vacillate around the square root of the unconditional variance $(\sigma)$ like the following equation:

$$
\sigma_{t}^{2}=\operatorname{Var}(r)=\frac{w}{1-\alpha-\frac{\gamma}{2}-\beta} .
$$

\section{RESULTS}

This section gives the descriptive analysis and techniques that test the effect of Ramadan month and other months in the stock returns in Palestine.

\subsection{Descriptive analysis}

Table 1 shows the closing price for all sectors in Shaaban, Ramadan, and Shawwal months. It is clear that the overall average of the closing price in the Palestine Stock Exchange is 4.629 with a standard deviation 3.347. It is clear that the mean of closing price in the insurance, banking, and services sectors is the highest among other sectors. This is because the companies try to use hedging strategies to ensure the safety of their real states before Ramadan month. Besides, the companies were reducing the workload during Ramadan, so they complete all complex tasks/duties before Ramadan. People and companies are willing to spend more during Ramadan month, and that is why the closing price in the banking sector is high. Moreover, services companies are working more during Ramadan month, as people would have

\begin{tabular}{|c|c|c|c|c|}
\hline Month & Sector & Total & Mean & $\begin{array}{l}\text { Standard } \\
\text { deviation }\end{array}$ \\
\hline \multirow{5}{*}{$\begin{array}{l}\text { Shaaban } \\
\text { month }\end{array}$} & $\begin{array}{l}\text { Banking } \\
\text { sector }\end{array}$ & 7496.22 & 5.038 & 3.547 \\
\hline & $\begin{array}{c}\text { Insurance } \\
\text { sector }\end{array}$ & 5363.03 & 5.406 & 4.862 \\
\hline & $\begin{array}{c}\text { Investment } \\
\text { sector }\end{array}$ & 7800.39 & 4.546 & 3.403 \\
\hline & $\begin{array}{l}\text { Industry } \\
\text { sector }\end{array}$ & 8671.27 & 3.920 & 2.750 \\
\hline & $\begin{array}{l}\text { Services } \\
\text { sector }\end{array}$ & 7435.47 & 5.068 & 3.057 \\
\hline \multicolumn{2}{|c|}{ Total of Shaaban month } & 36766.38 & 4.669 & 3.467 \\
\hline \multirow{5}{*}{$\begin{array}{l}\text { Ramadan } \\
\text { month }\end{array}$} & $\begin{array}{l}\text { Banking } \\
\text { sector }\end{array}$ & 7680.82 & 4.981 & 3.544 \\
\hline & $\begin{array}{l}\text { Insurance } \\
\text { sector }\end{array}$ & 5193.09 & 5.052 & 3.982 \\
\hline & $\begin{array}{c}\text { Investment } \\
\text { sector }\end{array}$ & 7960.9 & 4.480 & 3.286 \\
\hline & $\begin{array}{l}\text { Industry } \\
\text { sector }\end{array}$ & 9288.95 & 4.055 & 2.833 \\
\hline & $\begin{array}{l}\text { Services } \\
\text { sector }\end{array}$ & 7452.02 & 4.899 & 3.067 \\
\hline \multicolumn{2}{|c|}{ Total of Ramadan month } & 37575.78 & 4.605 & 3.299 \\
\hline \multirow{5}{*}{$\begin{array}{l}\text { Shawwal } \\
\text { month }\end{array}$} & $\begin{array}{l}\text { Banking } \\
\text { sector }\end{array}$ & 7454.97 & 5.030 & 3.566 \\
\hline & $\begin{array}{c}\text { Insurance } \\
\text { sector }\end{array}$ & 5157.8 & 5.220 & 3.945 \\
\hline & $\begin{array}{c}\text { Investment } \\
\text { sector }\end{array}$ & 7521.22 & 4.404 & 3.177 \\
\hline & $\begin{array}{l}\text { Industry } \\
\text { sector }\end{array}$ & 8984.89 & 4.080 & 2.855 \\
\hline & $\begin{array}{l}\text { Services } \\
\text { sector }\end{array}$ & 7072.75 & 4.838 & 3.017 \\
\hline \multicolumn{2}{|c|}{ Total of Shawwal month } & 36191.63 & 4.615 & 3.274 \\
\hline \multicolumn{2}{|l|}{ Total } & 110533.79 & 4.629 & 3.347 \\
\hline
\end{tabular}
more time for shopping.

Table 1. Closing price 
Table 2 presents the trading values in the three months. It is clear that the general average value of trading in the PEX is 1131.557 with a standard deviation of 7519.933. It is clear from Table 2 that the largest trading value of the months is Shaaban month. It also shows that the standard deviation is higher than the means of traded values in each sector. This is due to the high fluctuation in the trading values where some companies showed very low trading activity, while others showed a very high trading activity. This is justified by the nature of the Palestinian market, which is affected by the current political conflicts and tensions in the region. Besides, it is clear that the mean of closing price in the insurance, banking, and services sectors is also high, as explained earlier.

Table 2. Trading value

\begin{tabular}{|c|c|c|c|c|}
\hline Month & Sector & Total & Mean & $\begin{array}{l}\text { Standard } \\
\text { deviation }\end{array}$ \\
\hline \multirow{5}{*}{$\begin{array}{l}\text { Shaaban } \\
\text { month }\end{array}$} & $\begin{array}{l}\text { Banking } \\
\text { sector }\end{array}$ & 185853.54 & 130.424 & 215.811 \\
\hline & $\begin{array}{c}\text { Insurance } \\
\text { sector }\end{array}$ & 7757860.73 & 8030.912 & 19950.187 \\
\hline & $\begin{array}{l}\text { Investment } \\
\text { sector }\end{array}$ & 383086.67 & 223.244 & 282.735 \\
\hline & $\begin{array}{l}\text { Industry } \\
\text { sector }\end{array}$ & 254648.18 & 117.295 & 186.213 \\
\hline & $\begin{array}{l}\text { Services } \\
\text { sector }\end{array}$ & 209962.76 & 141.104 & 198.138 \\
\hline \multicolumn{2}{|c|}{$\begin{array}{l}\text { Total of Shaaban } \\
\text { month }\end{array}$} & 8791411.88 & 1132.039 & 7501.332 \\
\hline \multirow{5}{*}{$\begin{array}{l}\text { Ramadan } \\
\text { month }\end{array}$} & $\begin{array}{l}\text { Banking } \\
\text { sector }\end{array}$ & 202028.49 & 136.876 & 221.597 \\
\hline & $\begin{array}{l}\text { Insurance } \\
\text { sector }\end{array}$ & 8077987.14 & 8029.808 & 19918.992 \\
\hline & $\begin{array}{l}\text { Investment } \\
\text { sector }\end{array}$ & 382357.61 & 215.170 & 275.016 \\
\hline & $\begin{array}{l}\text { Industry } \\
\text { sector }\end{array}$ & 261678.77 & 116.405 & 187.013 \\
\hline & $\begin{array}{l}\text { Services } \\
\text { sector }\end{array}$ & 183487.66 & 118.993 & 190.701 \\
\hline \multicolumn{2}{|c|}{$\begin{array}{l}\text { Total of Ramadan } \\
\text { month }\end{array}$} & 9107539.67 & 1131.512 & 7509.215 \\
\hline \multirow{5}{*}{$\begin{array}{l}\text { Shawwal } \\
\text { month }\end{array}$} & $\begin{array}{l}\text { Banking } \\
\text { sector }\end{array}$ & 198250.08 & 139.221 & 224.369 \\
\hline & $\begin{array}{c}\text { Insurance } \\
\text { sector }\end{array}$ & 7737904.44 & 8001.969 & 20060.801 \\
\hline & $\begin{array}{l}\text { Investment } \\
\text { sector }\end{array}$ & 379110.99 & 221.962 & 277.440 \\
\hline & $\begin{array}{l}\text { Industry } \\
\text { sector }\end{array}$ & 254264.2 & 117.715 & 188.825 \\
\hline & $\begin{array}{l}\text { Services } \\
\text { sector }\end{array}$ & 186466.28 & 125.821 & 199.613 \\
\hline \multicolumn{2}{|c|}{$\begin{array}{l}\text { Total of Shawwal } \\
\text { month }\end{array}$} & 8755995.99 & 1131.120 & 7550.617 \\
\hline \multicolumn{2}{|l|}{ Total } & 26654947.54 & 1131.557 & 7519.933 \\
\hline
\end{tabular}

Table 3 shows the number of trades in the Palestinian stock market during the three months. It is clear that the overall average of the trade numbers in the Palestine Stock Exchange is 19.527 with a standard deviation 5.638. It is clear from Table 3 that the highest number of trades is occurred in of Shawwal month, which is the insurance sector. The result indicates that insurance company are increasing their insurance to meet the extra work of other companies, especially after the end of Eid Al-Fitr.

Table 3. Number of trades

\begin{tabular}{|c|c|c|c|}
\hline Month & Sector & Mean & $\begin{array}{l}\text { Standard } \\
\text { deviation }\end{array}$ \\
\hline \multirow{5}{*}{$\begin{array}{l}\text { Shaaban } \\
\text { month }\end{array}$} & Banking sector & 20.524 & 7.118 \\
\hline & $\begin{array}{l}\text { Insurance } \\
\text { sector }\end{array}$ & 15.587 & 8.638 \\
\hline & $\begin{array}{l}\text { Investment } \\
\text { sector }\end{array}$ & 20.521 & 6.174 \\
\hline & Industry sector & 21.874 & 7.637 \\
\hline & Services sector & 16.328 & 8.174 \\
\hline \multicolumn{2}{|c|}{ Total of Shaaban month } & 17.658 & 7.998 \\
\hline \multirow{5}{*}{$\begin{array}{l}\text { Ramadan } \\
\text { month }\end{array}$} & Banking sector & 20.225 & 4.395 \\
\hline & $\begin{array}{l}\text { Insurance } \\
\text { sector }\end{array}$ & 21.635 & 6.935 \\
\hline & $\begin{array}{l}\text { Investment } \\
\text { sector }\end{array}$ & 27.635 & 7.251 \\
\hline & Industry sector & 25.874 & 6.125 \\
\hline & Services sector & 30.966 & 7.635 \\
\hline \multicolumn{2}{|c|}{ Total of Ramadan month } & 28.741 & 5.881 \\
\hline \multirow{5}{*}{$\begin{array}{l}\text { Shawwal } \\
\text { month }\end{array}$} & Banking sector & 16.529 & 11.638 \\
\hline & $\begin{array}{l}\text { Insurance } \\
\text { sector }\end{array}$ & 21.638 & 6.839 \\
\hline & $\begin{array}{l}\text { Investment } \\
\text { sector }\end{array}$ & 19.668 & 6.985 \\
\hline & Industry sector & 20.714 & 6.871 \\
\hline & Services sector & 20.396 & 5.963 \\
\hline \multicolumn{2}{|c|}{ Total of Shawwal month } & 21.398 & 3.987 \\
\hline \multicolumn{2}{|l|}{ Total } & 19.527 & 5.638 \\
\hline
\end{tabular}

From Table 4, it is clear that the general average price of the stock in Palestine Stock Exchange is 3.2 with a standard deviation of 2.412. Table 4 shows that the highest share price of the months was in Shawwal and Ramadan months. In all sectors, the standard deviation is relatively high compared to the means. This indicates that the prices have a high volatility due to unstable situations and political conflict in Palestine. 
Table 4. Share price

\begin{tabular}{|c|c|c|c|c|}
\hline Month & Sector & Total & Mean & $\begin{array}{l}\text { Standard } \\
\text { deviation }\end{array}$ \\
\hline \multirow{5}{*}{$\begin{array}{l}\text { Shaaban } \\
\text { month }\end{array}$} & $\begin{array}{l}\text { Banking } \\
\text { sector }\end{array}$ & 4668.39 & 3.137 & 2.728 \\
\hline & $\begin{array}{l}\text { Insurance } \\
\text { sector }\end{array}$ & 3790.3 & 3.821 & 3.568 \\
\hline & $\begin{array}{l}\text { Investment } \\
\text { sector }\end{array}$ & 5860.28 & 3.415 & 2.116 \\
\hline & $\begin{array}{l}\text { Industry } \\
\text { sector }\end{array}$ & 6012.08 & 2.718 & 1.951 \\
\hline & $\begin{array}{l}\text { Services } \\
\text { sector }\end{array}$ & 4342.47 & 3.184 & 1.777 \\
\hline \multicolumn{2}{|c|}{ Total of Shaaban month } & 24673.52 & 3.175 & 2.408 \\
\hline \multirow{5}{*}{$\begin{array}{l}\text { Ramadan } \\
\text { month }\end{array}$} & $\begin{array}{l}\text { Banking } \\
\text { sector }\end{array}$ & 4775.14 & 3.097 & 2.701 \\
\hline & $\begin{array}{l}\text { Insurance } \\
\text { sector }\end{array}$ & 4095.79 & 3.984 & 3.564 \\
\hline & $\begin{array}{l}\text { Investment } \\
\text { sector }\end{array}$ & 5910.16 & 3.326 & 2.067 \\
\hline & $\begin{array}{l}\text { Industry } \\
\text { sector }\end{array}$ & 6529.38 & 2.850 & 2.056 \\
\hline & $\begin{array}{l}\text { Services } \\
\text { sector }\end{array}$ & 4457.06 & 3.154 & 1.791 \\
\hline \multicolumn{2}{|c|}{ Total of Ramadan month } & 25767.53 & 3.201 & 2.417 \\
\hline \multirow{5}{*}{$\begin{array}{l}\text { Shawwal } \\
\text { month }\end{array}$} & $\begin{array}{l}\text { Banking } \\
\text { sector }\end{array}$ & 4630.98 & 3.125 & 2.652 \\
\hline & $\begin{array}{l}\text { Insurance } \\
\text { sector }\end{array}$ & 4015.76 & 4.065 & 3.597 \\
\hline & $\begin{array}{l}\text { Investment } \\
\text { sector }\end{array}$ & 5948.37 & 3.483 & 2.064 \\
\hline & $\begin{array}{l}\text { Industry } \\
\text { sector }\end{array}$ & 6051.74 & 2.748 & 1.985 \\
\hline & $\begin{array}{l}\text { Services } \\
\text { sector }\end{array}$ & 4303.58 & 3.164 & 1.815 \\
\hline \multicolumn{2}{|c|}{ Total of Shawwal month } & 24950.43 & 3.224 & 2.410 \\
\hline \multicolumn{2}{|l|}{ Total } & 75391.48 & 3.200 & 2.412 \\
\hline
\end{tabular}

From Table 5, it is clear that the general average of trading volume in Palestine Stock Exchange is 412.216 with a standard deviation of 41.248 and this indicates that the trading volume is normal to some extent. Considering Table 3 and Table 5 together, it is clear that there is a relationship between the number of trades and the trading volume. The sectors that show a high number of trades, also showed a higher trading volume. This means the companies with high trading volume are trying to make more profit and to lead the market.

Table 5. Trading volume

\begin{tabular}{|c|c|c|c|c|}
\hline Month & Sector & Total & Mean & $\begin{array}{l}\text { Standard } \\
\text { deviation }\end{array}$ \\
\hline \multirow{5}{*}{$\begin{array}{l}\text { Shaaban } \\
\text { month }\end{array}$} & Banking sector & 8232.412 & 24.525 & 3.528 \\
\hline & $\begin{array}{l}\text { Insurance } \\
\text { sector }\end{array}$ & 68101.2 & 13.521 & 3.568 \\
\hline & $\begin{array}{l}\text { Investment } \\
\text { sector }\end{array}$ & 116352.21 & 12.357 & 2.116 \\
\hline & Industry sector & 120212.521 & 13.529 & 3.525 \\
\hline & Services sector & 8623.52 & 25.526 & 3.878 \\
\hline \multicolumn{2}{|c|}{ Total of Shaaban month } & 285.665 & 24.673 & 16.527 \\
\hline \multirow{5}{*}{$\begin{array}{l}\text { Ramadan } \\
\text { month }\end{array}$} & Banking sector & 844123.521 & 19.529 & 9.857 \\
\hline & $\begin{array}{l}\text { Insurance } \\
\text { sector }\end{array}$ & 82541.25 & 17.521 & 10.524 \\
\hline & $\begin{array}{l}\text { Investment } \\
\text { sector }\end{array}$ & 59321.215 & 22.714 & 11.638 \\
\hline & Industry sector & 663254.25 & 19.521 & 11.874 \\
\hline & Services sector & 887478.52 & 13.521 & 10.33 \\
\hline \multicolumn{2}{|c|}{ Total of Ramadan month } & 854.752 & 21.755 & 9.632 \\
\hline \multirow{5}{*}{$\begin{array}{l}\text { Shawwal } \\
\text { month }\end{array}$} & Banking sector & 12352.52 & 28.854 & 11.527 \\
\hline & $\begin{array}{l}\text { Insurance } \\
\text { sector }\end{array}$ & 2523.52 & 29.527 & 12.934 \\
\hline & $\begin{array}{c}\text { Investment } \\
\text { sector }\end{array}$ & 354521.52 & 30.517 & 11.398 \\
\hline & Industry sector & 2325.52 & 25.847 & 19.742 \\
\hline & Services sector & 5253.52 & 15.563 & 20.63 \\
\hline \multicolumn{2}{|c|}{ Total of Shawwal month } & 875.452 & 24.950 & 13.553 \\
\hline \multicolumn{2}{|l|}{ Total } & 412.216 & 23.435 & 41.248 \\
\hline
\end{tabular}

It is clear from Table 6 that the overall average of the volatility in the Palestine Stock Exchange is 6.884 with a standard deviation 4.897. The results of Table 6 show that the highest volatility of the three months is in Shaaban month. The highest volatility indicates the instability of all due to market instability and political conditions in Palestine. 
Table 6. Volatility

\begin{tabular}{|c|c|c|c|}
\hline Month & Sector & Mean & $\begin{array}{l}\text { Standard } \\
\text { deviation }\end{array}$ \\
\hline \multirow{5}{*}{$\begin{array}{l}\text { Shaaban } \\
\text { month }\end{array}$} & Banking sector & 7.521 & 6.973 \\
\hline & Insurance sector & 6.871 & 6.881 \\
\hline & $\begin{array}{l}\text { Investment } \\
\text { sector }\end{array}$ & 7.214 & 6.879 \\
\hline & Industry sector & 9.623 & 8.412 \\
\hline & Services sector & 10.875 & 6.974 \\
\hline \multicolumn{2}{|c|}{ Total of Shaaban month } & 8.874 & 7.998 \\
\hline \multirow{5}{*}{$\begin{array}{l}\text { Ramadan } \\
\text { month }\end{array}$} & Banking sector & 5.365 & 3.587 \\
\hline & Insurance sector & 3.552 & 5.741 \\
\hline & $\begin{array}{c}\text { Investment } \\
\text { sector }\end{array}$ & 3.874 & 3.812 \\
\hline & Industry sector & 6.668 & 5.113 \\
\hline & Services sector & 7.589 & 5.559 \\
\hline \multicolumn{2}{|c|}{ Total of Ramadan month } & 6.183 & 5.881 \\
\hline \multirow{5}{*}{$\begin{array}{l}\text { Shawwal } \\
\text { month }\end{array}$} & Banking sector & 6.587 & 5.874 \\
\hline & Insurance sector & 5.220 & 6.839 \\
\hline & $\begin{array}{l}\text { Investment } \\
\text { sector }\end{array}$ & 8.784 & 5.878 \\
\hline & Industry sector & 9.541 & 6.578 \\
\hline & Services sector & 6.587 & 6.874 \\
\hline \multicolumn{2}{|c|}{ Total of Shawwal month } & 7.589 & 6.898 \\
\hline \multicolumn{2}{|l|}{ Total } & 6.884 & 4.897 \\
\hline
\end{tabular}

\subsection{Stationary test}

Table 7 shows the results of ADF for the stationary tests. The results for all sectors are negative for both with constant and with constant and trend. It shows -57.387 for banking sector and -20.578 for industry sector. The same results can be drawn for with constant and trend. This leads us to say the series is stationary, which helps us to proceed for further analyses.

Table 7. Augmented Dickey-Fuller unit root tests for return series

\begin{tabular}{|c|c|c|c|c|}
\hline \multirow{2}{*}{ Sector } & \multicolumn{2}{|c|}{ With constant } & \multicolumn{2}{|c|}{$\begin{array}{l}\text { With constant } \\
\text { and trend }\end{array}$} \\
\hline & T statistic & Lag & $\begin{array}{c}T \\
\text { statistic }\end{array}$ & Lag \\
\hline $\begin{array}{l}\text { Banking and } \\
\text { financial services } \\
\text { sector }\end{array}$ & -57.387 & 2 & -49.537 & 1 \\
\hline Insurance sector & -49.253 & 2 & -43.698 & 1 \\
\hline Investment sector & -40.635 & 1 & -53.117 & 2 \\
\hline Services sector & -42.235 & 1 & -59.674 & 2 \\
\hline Industry sector & -20.578 & 3 & -66.871 & 1 \\
\hline
\end{tabular}

\subsection{Model estimation}

Table 8 shows the regression results of GARCH model, as stated in equation 1 . The results in Table 8 show the values of adjusted $R^{2}, F$ test value, and the significance ( $p$-value) for the three months, Shaaban, Ramadan, and Shawwal. It gives a detailed analysis for Ramadan month, i.e., for first trimester, second trimester, and third trimester. The results of Ramadan month indicate a significant impact on the earnings per share in the PEX. The mean value of transactions was less than 0.05 in all independent variables. It is also evident that the value of the adjusted coefficient of 0.710 means that the ratio of independent variable interpretation to the dependent variable is $71 \%$, and that $29 \%$ are other variables outside the study. It is also clear that the value of the significance level is less than 0.05 , and the return on the stock in Ramadan month and in the second and third trimesters was significant and more influential than in the second trimester.

For Shaaban month, the results show that the value of the significance level of the transactions was less than 0.05 in the share price and trading volume. The value of the transaction level is more than 0.05 in the closing price, the trading value, the number of transactions, and the volatility. This means that the return on the share in Shaaban month did not affect the closing price.

It is also clear that the value of $R^{2}$ for is 0.667 , which means that the independent variable's interpretation rate on the dependent variable is $66.7 \%$, and that $33.3 \%$ are other variables outside the study. It is also clear that the value of the significance level for the $p$ test is more than the significance level 0.05. Table 6 also shows the results of Shawwal month. It shows that the mean value of the coefficients was less than 0.05 in all the independent variables. This means that the variables are significant in the model. It is also clear that the value of the coefficient of determination is 0.709 . This means that the independent variable is explaining 70.9 of the changes in the dependent variables. The value of the significance level for the $p$ test is below the significance level of 0.05 , which means that the model is significant and effective. This means that the return on the stock in Shawwal month is effective because of its impact in Ramadan month. 
Table 8. Model estimation results

\begin{tabular}{|c|c|c|c|c|c|c|c|c|c|c|c|}
\hline \multirow{2}{*}{ Month } & \multirow{2}{*}{ Parameters } & \multicolumn{7}{|c|}{ Regression equation } & \multirow{2}{*}{$\begin{array}{c}R^{2} \\
\text { adjustment }\end{array}$} & \multirow{2}{*}{$F$ test } & \multirow{2}{*}{ Sig. } \\
\hline & & Constant & Close price & Stock price & Traded value & Trade volume & Trade \# & Volatility & & & \\
\hline \multirow{2}{*}{ Shaaban } & B & 0.0013 & 0.174 & 0.877 & 0.897 & 0.568 & 1.558 & 1.687 & \multirow{2}{*}{0.667} & \multirow{2}{*}{2.551} & \multirow{2}{*}{0.127} \\
\hline & Sig & 0.000 & 0.291 & 0.037 & 0.068 & 0.021 & 0.510 & 0.581 & & & \\
\hline \multirow{2}{*}{ Ramadan } & B & 0.0017 & 0.521 & 0.478 & 1.521 & 1.327 & 2.554 & 1.589 & \multirow{2}{*}{0.710} & \multirow{2}{*}{11.238} & \multirow{2}{*}{0.000} \\
\hline & Sig & 0.001 & 0.015 & 0.000 & 0.001 & 0.014 & 0.000 & 0.0002 & & & \\
\hline \multirow{2}{*}{ First trimester } & B & 0.0012 & 0.512 & 0.417 & 0.412 & 0.874 & 0.651 & 1.521 & \multirow{2}{*}{0.699} & \multirow{2}{*}{9.528} & \multirow{2}{*}{0.000} \\
\hline & Sig & 0.000 & 0.001 & 0.002 & 0.002 & 0.000 & 0.002 & 0.004 & & & \\
\hline \multirow{2}{*}{ Second trimester } & B & 0.0010 & 0.798 & 1.587 & 1.501 & 2.787 & 1.774 & 2.638 & \multirow{2}{*}{0.587} & \multirow{2}{*}{6.558} & \multirow{2}{*}{0.021} \\
\hline & Sig & 0.000 & 0.114 & 0.474 & 0.527 & 0.001 & 0.003 & 0.417 & & & \\
\hline \multirow{2}{*}{ Third trimester } & B & 0.0028 & 1.877 & 1.889 & 2.057 & 1.882 & 0.231 & 0.557 & \multirow{2}{*}{0.711} & \multirow{2}{*}{13.554} & \multirow{2}{*}{0.000} \\
\hline & Sig & 0.000 & 0.001 & 0.000 & 0.003 & 0.000 & 0.001 & 0.000 & & & \\
\hline \multirow{2}{*}{ Shawwal } & B & 0.0018 & 1.117 & 1.974 & 2.441 & 0.036 & 2.557 & 0.598 & \multirow{2}{*}{0.709} & \multirow{2}{*}{25.214} & \multirow{2}{*}{0.000} \\
\hline & Sig & 0.000 & 0.0000 & 0.000 & 0.000 & 0.000 & 0.041 & 0.014 & & & \\
\hline
\end{tabular}




\section{DISCUSSION}

This section discusses the impact of Ramadan month on different sectors at the Palestine Stock Exchange. There are five sectors under the study to test this vital relationship, as discussed further.

\subsection{Banking sector}

In this section, this equation was used:

$$
R=0.0013+0.025 \cdot \lambda+0.037 \cdot \varphi_{1}
$$

where $\lambda$ - stock returns, $\varphi$ - market value are used to find the impact of stock return and market value of the banking sector on the returns of Ramadan month. The equation clarifies that the coefficients are positive in the stock returns and market value. This means that there is a positive relationship between the stock returns and the market value in Ramadan. However, the variance coefficients of this equation show that the significance level is not relevant at the significance level of 0.05 (the significance level is greater than 0.05 for the coefficients of stock returns and market value in banking sector and stock exchange). Therefore, there is no direct relationship between these variables in Ramadan stock returns.

\subsection{Insurance sector}

The following formula is used:

$$
\begin{aligned}
& R=0.00058-0.00079 \cdot \lambda+ \\
& +0.0535 \cdot \varphi_{1}-0.048 \cdot \varphi_{2},
\end{aligned}
$$

where $\lambda$ - stock returns, $\varphi-$ market value $\varphi$ - closing price are used to examine the impact of the stock return, market value, and closing price of the insurance sector in Ramadan month. The equation clarifies that the coefficients are positive in market value and negative in stock returns and the closing price. This means that there is a positive relationship between market value and Ramadan, and the negative relationship between Ramadan, market value, and closing price. However, the variance coefficients for this equation show that the significance level is not relevant at the significance level of 0.05 (the significance level is greater than 0.05 for the coefficients of stock returns, market value, and closing price in the insurance sector).
Therefore, there is no relationship between these variables and Ramadan month.

\subsection{Investment sector}

The following equation tests the relationship between Ramadan and the stock returns, market value, and stock price of the investment sector. The formula is as follows:

$$
\begin{aligned}
& R=0.00097+0.00089 \cdot \lambda+ \\
& +0.089 \cdot \varphi_{2}-0.931 \cdot \phi,
\end{aligned}
$$

where $\lambda$ - stock returns, $\varphi$ - market value, $\phi$ stock price are used. The equation clarifies that the coefficients are positive in closing price and market value and negative in stock price. This means that there is a positive relationship between closing price, market value, and Ramadan and negative relationship between Ramadan and stock price. However, the variance coefficients for this equation show that the significance level is relevant at the value of 0.05 . Therefore, there is a relationship between these variables and Ramadan.

\subsection{Services sector}

This part depicts the relationship between Ramadan and the services sector. The following equation is used:

$$
\begin{aligned}
& R=0.00093-0.00053 \cdot \lambda+ \\
& +0.0038 \cdot \varphi_{1}+0.039 \cdot \varphi_{2},
\end{aligned}
$$

where $\lambda$ - stock returns, $\varphi$ - market value, $\phi-$ closing price are used. The equation clarifies that the coefficients are positive in closing price and market value and negative in stock price. This means that there is a positive relationship between closing price the market value and Ramadan and the negative relationship between Ramadan and stock returns. However, the variance coefficients for this equation show that the significance level is relevant at the value of 0.05 . Therefore, there is a relationship between these variables and Ramadan.

\subsection{Industry sector}

This section shows the relationship between Ramadan, stock returns, and market value. The equation is as follows: 
Table 9. Diagnostic test

\begin{tabular}{|c|c|c|c|c|c|c|c|c|}
\hline \multirow{3}{*}{ Sector } & \multicolumn{4}{|c|}{ Ljung box test } & & & & \\
\hline & \multicolumn{2}{|c|}{$\begin{array}{l}\text { Standardized } \\
\text { residuals }\end{array}$} & \multicolumn{2}{|c|}{$\begin{array}{l}\text { Squared standardized } \\
\text { residuals }\end{array}$} & \multicolumn{4}{|c|}{ LM tests } \\
\hline & $T$ test & Sig & $T$ test & Sig & $F$ test & Sig & $\mathbf{T}^{*} \mathbf{R}^{2}$ & Sig \\
\hline Banking sector & 15.368 & 0.148 & 10.536 & 0.408 & 1.087 & 0.382 & 10.732 & 0.395 \\
\hline Insurance sector & 10.584 & 0.327 & 10.653 & 0.401 & 1.065 & 0.402 & 10.553 & 0.386 \\
\hline Investment sector & 20.466 & 0.003 & 8.001 & 0.803 & 0.709 & 0.818 & 8.000 & 0.739 \\
\hline Services sector & 5.847 & 0.987 & 20.158 & 0.002 & 2.032 & 0.040 & 20.135 & 0.138 \\
\hline Industry sector & 20.210 & 0.023 & 7.365 & 0.835 & 0.718 & 0.817 & 7.659 & 0.857 \\
\hline
\end{tabular}

$R=0.0029-0.00047 \cdot \lambda+0.060 \cdot \varphi_{1}$,

where $\lambda$ - stock returns, $\varphi$ - market value are used. The equation clarifies that the coefficients are positive in the market value and negative stock returns. This means that there is a positive relationship between the market value and Ramadan and the negative relationship between Ramadan and stock returns. However, the variance coefficients for this equation show that the significance level is relevant at the value of 0.05 . Therefore, there is a relationship between these variables and Ramadan. From the previous literature review, it is clear that the industry sector takes the first place in the effect of Ramadan on stock returns, market value, closing price, stock price, followed by service sector and then investment sector. Table 9 shows no autocorrelation between independent variables in industry and investment sectors, while there is autocorrelation in banking, insurance, and services sectors. Thus, it needs a mathematical equation like a fractional equation. LM test ratio is used to determine the heterogeneity of variance of the predicted models. The previous table shows that the value of significant level of $p$ test is more than significance level of 0.05 , which means that there is a homogeneity of variance and the variances are unified between sectors.

\section{CONCLUSION}

This study aimed to analyze Ramadan effect on stock returns at the PEX. The study is helpful to the interested stakeholders. The results also showed a positive significant Ramadan effect on the stock returns in the PEX. The mean return in Ramadan is greater than the mean return in all other days of the year. The study also checked the mean changes before, during, and after Ramadan. The mean return during the last ten days of Ramadan is higher as compared to first ten days of Ramadan and other months. This study helps in implementing the regulations and policies to control the action of stock market if an anomaly is found in a specific point to improve its efficiency. Besides, it helps to attract, regain, and guarantee the confidentiality of the investor in the stock market of Palestine. As for investors, the study paves the road for the investors and stock dealers in their higher cognitive process to extend the worth of their wealth. If any anomaly is discovered, they are going to cash it to create profitable commerce. For academics, there are few studies regarding the impact of Ramadan month on stock returns, particularly within the developing countries like Palestine. The study brought new insights into stock markets in Palestine and to Islamic finance industry in which Ramadan effect is vital to many investors in the area.

The results of this study will increase the transparency, disclosure, and information in Palestine stock markets, which will help all investors around the globe to come and invest in Palestine. For the Palestinian government, the stock market's performance is a part of economic performance. The inefficient performance of markets is a signal of economic and monetary issues of any economy. This study can help in analyzing the economic performance of any country. The Palestinian government as a regulator of stock exchanges through the PEX are going to be ready to monitor the stock market performance. This could help in attracting each native and foreign investor and building a viable investment environment. 


\section{RECOMMENDATIONS}

Based on the analysis of the paper, the following recommendations are given:

- $\quad$ Ramadan has a remarkable impact on the PEX; therefore, shareholders should benefit from this;

- $\quad$ the profits are increasing in the industrial and investment companies due to the high demands in Ramadan; therefore, the companies should work and be ready to meet the high demand in Ramadan;

- $\quad$ some external factors such as siege, war, and settlement - other than the month of Ramadan - led to a decrease in the profits. Thus, it is important for the companies to set strategies to deal with those abnormal factors.

\section{AUTHOR CONTRIBUTIONS}

Conceptualization: Ashraf Hijazi.

Formal analysis: Mosab Tabash.

Investigation: Ashraf Hijazi.

Methodology: Ashraf Hijazi.

Supervision: Mosab Tabash.

Writing - original draft: Ashraf Hijazi.

Writing - review \& editing: Mosab Tabash.

\section{REFERENCES}

1. Aduda, J., Odera, E. O., \& Onwonga, M. (2012). The behaviour and financial performance of individual investors in the trading shares of companies listed at the Nairobi stock exchange, Kenya. Journal of Finance and Investment Analysis, 1(3), 33-60. Retrieved from https:// ideas.repec.org/a/spt/fininv/ v1y2012i3f1_3_3.html

2. Al-Ississ, M. (2010). The impact of religious experience on financial markets. Harvard Kennedy School of Government. Retrieved from http://citeseerx.ist.psu.edu/viewdoc/download?doi=10.1.1.497.395 $0 \&$ rep $=$ rep $1 \&$ type $=$ pdf

3. Alper, C. E., \& Aruoba, S. B. (2001). Deseasonalizing macroeconomic data: A caveat to applied researchers in Turkey. Istanbul Stock Exchange Review, 5(18), 3352. Retrieved from http://econweb. umd.edu/ webspace/aruoba/ research/paper1/Alper_Aruoba_2001_English.pdf

4. Alrashidi, F. (2013). Comparison of the performance of Islamic mutual funds vs. ethical and conventional mutual funds (Doctoral dissertation, Durham University).

5. Arbel, A., \& Strebel, P. (1983). Pay attention to neglected firms. Journal of Portfolio Management, 9(2), 37-42. https:// doi.org/10.3905/jpm.1983.408901

6. Białkowski, J., Etebari, A., \& Wisniewski, T. P. (2012). Fast profits: Investor sentiment and stock returns during Ramadan. Journal of Banking \& Finance, 36(3), 835-845. https://doi. org/10.1016/j.jbankfin.2011.09.014

7. Bley, J., \& Saad, M. (2010). Cross cultural differences in seasonality. International Review of Financial Analysis, 19, 306-312. https://doi. org/10.1016/j.irfa.2010.08.004

8. Branch, B. (1977). A Tax Loss Trading. Journal of Business, 50 , 198-207.

9. Chowdhury, T. S., \& Mostari, S. (2015). Impact of Eid-ul-Azha on market return in Dhaka stock exchange. IOSR Journal of Business and Management, 17, 25-29. https://doi.org/10.6084/ M9.FIGSHARE.1348596
10. Dodd, O., \& Gakhovich, A. (2011). The holiday effect in Central and Eastern European financial markets. Investment Management and Financial Innovations, 8(4), 29-35. Retrieved from https:// businessperspectives.org/images/pdf/applications/publishing/ templates/article/assets/4323/ imfi_en_2011_04_Dodd.pdf

11. Fama, E. F. (1970). Efficient capital markets: A review of theory and empirical work. Journal of Finance, 25(2), 383-417.

12. Frankfurter, G. M., \& McGoun, E. G. (2001). Anomalies in finance: What are they and what are they good for? International Review of Financial Analysis, 10(4), 407-429. https://doi.org/10.1016/S10575219(01)00061-8

13. Glosten, L., Jagannathan, R., \& Runkle, D. (1993). On the relation between expected value and the volatility of the nominal excess return on stocks. Journal of Finance, 48, 1779-1801. https:// doi.org/10.1111/j.1540-6261.1993. tb05128.x 
14. Husain, F. (1998). A Seasonality in the Pakistani Equity Market: The Ramadan Effect. Pakistan Development Review, 37(1), 77-81. Retrieved from https://ssrn.com/ abstract $=992144$

15. Jensen, M. (1978). Some anomalous evidence regarding market efficiency. Journal of Financial Economics, 6(2/3), 95101. https://doi.org/10.1016/0304405X(78)90025-9

16. Khan, A., Sarim, M., Tabash, M. I., \& Akhtar, A. (2018). Examining anomalies in Islamic equity market of the emerging economies. Economic Annals-XXI, 170(3-4), 64-68. https://doi.org/10.21003/ ea.V170-11

17. Kiymaz, H., \& Berument, $\mathrm{H}$. (2003). The day of the week effect on stock market volatility and volume: International evidence. Review of Financial Economics, 12(4), 363-380. https://doi.org/10.1016/S10583300(03)00038-7

18. Kulavi, C. M. (2013). The day of the week effect and stock market volatility: evidence from Nairobi securities exchange (Doctoral dissertation, University of Nairobi).

19. Latif, M., Arshad, S., Fatima, M., \& Farooq, S. (2011). Market efficiency, market anomalies, causes, evidences, and some behavioral aspects of market anomalies. Research Journal of Finance and Accounting, 2(9), 1-13. Retrieved from http://citeseerx.ist. psu.edu/viewdoc/download?doi $=10.1 \cdot 1.831 .8635 \& \mathrm{rep}=$ rep $1 \&$ typ $\mathrm{e}=\mathrm{pdf}$

20. Lo, A. W. (2005). Reconciling efficient markets with behavioral finance: the adaptive markets hypothesis. Journal of Investment Consulting, 7(2), 21-44. Retrieved from https://ssrn.com/abstract $=1702447$

21. Majeed, U., Raheman, A., Sohail, M. K., Bhatti, G. A., \& Zulfiqar, B. (2015). Islamic calendar events and stock market reaction: Evidence from Pakistan. Science International Journal, 27, 25592567. Retrieved from https:// www.researchgate.net/publication/316432946_ISLAMIC_CAL-
ENDER_EVENTS_AND_STOCK_ MARKET_REACTION_EVIDENCE_FROM_PAKISTAN

22. Marrett, G. J., \& Worthington, A. C. (2007). An empirical note on the holiday effect in the Australian stock market, 19962006. Applied Economics Letters, 16(17), 1769-1772. https://doi. org/10.1080/13504850701675474

23. McGowan, C. B., \& Jakob, N. A. (2010). Is there an Eid al-Fitr effect in Malaysia? International Business \& Economics Research Journal, 9, 11-20. https://doi.org/10.19030/ iber.v9i4.549

24. Mustafa, K. (2008). The Islamic calendar effect on Karachi stock market. Global Business Review, 13(3), 562-574. Retrieved from https://www.researchgate.net/ publication/236147168_The_Islamic_calendar_effect_on_Karachi_stock_market

25. Osman, A. M. (2007). Study of holiday effect at the Nairobi stock exchange. Unpublished MBA project.

26. Pesaran, M. H. (2005). Market efficiency today (CFS Working Paper No. 2006/01).

27. Ramezani, A., Pouraghajan, A., \& Mardani, H. (2013). Studying impact of Ramadan on stock exchange index: Case of Iran. World of Science Journal, 1(12), 46-54.

28. Rasugu, N. C. (2005). The existence of the holiday effect in the Nairobi Stock Exchange (Unpublished MBA project). University of Nairobi.

29. Ray, S. (2012). Testing granger causal relationship between macroeconomic variables and stock price behaviour: evidence from India. Advances in Applied Economics and Finance, 3(1), 470 481. Retrieved from http://citeseerx.ist.psu.edu/viewdoc/download ?doi=10.1.1.477.2779\&rep=rep1\& type $=$ pdf

30. Reilly, J., \& Brown, J. (2004) Management and control of cost and risk for tunneling and infrastructure projects. In Proceedings of the 30th World Tunnel Congress, Singapore, May 22-27, 2004, 19(4-5).
31. Reinganum, M. R. (1992). A revival of the small-firm effect. Journal of Portfolio Management, 18(3), 55. https://doi. org/10.3905/jpm.1992.409404

32. Ritter, J. R. (1991). The longrun performance of initial public offerings. Journal of Finance, 46(1), 3-27. https://doi. org/10.1111/j.1540-6261.1991. tb03743.x

33. Schwert, G. W. (2003). Anomalies and market efficiency. Handbook of the Economics of Finance, 1, 939974. Retrieved from https://www. nber.org/papers/w9277.pdf

34. Seyyed, F. J., Abraham, A., \& Al-Hajji, M. (2005). Seasonality in stock returns and volatility: The Ramadan effect. Research in International Business and Finance, 19(3), 374-383. https://doi. org/10.1016/j.ribaf.2004.12.010

35. Sultan, A. B., \& Malik, Z. K. (2013). Impact of Anomalies in Form of Islamic Calendar Date (Eid-UlFitr) of Trading Values on The KSE Stock Prices. City University, Research Journal, 194.

36. Tabash, M. I., \& Dhankar, R. S. (2014). The flow of Islamic finance and economic growth: an empirical evidence of Middle East. Journal of Finance and Accounting, 2(1), 11-19. https://doi: 10.11648/j. jfa.20140201.12

37. Waithaka, G. L. (2013). Turn of the Month Effect on Stocks Listed at the NSE. Retrieved from www.nse. co.ke (accessed on 15/03/2018). 